\title{
An Investigation Of The Relation Between Corporate Governance And Liquidity: Empirical Evidence From France
}

\author{
Majdi Karmani, La Rochelle Business School, France \\ Aymen Ajina, University of Liege, Belgium \\ Rym Boussaada, ISG Tunis, Tunisia
}

\begin{abstract}
This study investigates the impact of corporate governance effectiveness on the market stock liquidity. It is innovative, since we study, on an order driven market, the global effect of corporate governance and the effect of specific governance sub-indexes. Drawing on a sample of 287 French firms from 2007 to 2012, we find that corporate governance is a significant determinant of stock liquidity. Indeed, companies with an effective corporate governance have a narrower spreads. That's mean that corporate governance may alleviate information asymmetry and improve the market stock liquidity of French companies. Our results are remarkably robust to other set of measures of liquidity as the effective spread measure and illiquidity ratio. These results suggest that firms may improve stock market liquidity by adopting best practices of corporate governance that mitigate informational asymmetries.
\end{abstract}

Keywords: Corporate Governance; Stock Liquidity; Information Asymmetry; Investor Protection

\section{INTRODUCTION}

1 $\mathrm{n}$ this paper we examine how the corporate governance effectiveness affects stock market liquidity. Several recent studies as the pioneer work of Edmans (2009) has proved that market liquidity is closely sensitive to blockholders trading. In fact, the blockholders monitoring induce managers to undertake efficient real investment through their informed trading of the firm's shares. These findings suggest that blockholders can exert governance even if they cannot intervene in a firm's operation. Another seminal work of Edmans et al. (2013) empirically test the relation between the stock market liquidity and the monitoring of firms by the blockholder on the basis of the channel of exit (trading). This research confirms that liquidity leads to an overall increase in both voice (intervention of the blockholder) and exit, thus such an improvement is beneficial to the effectiveness of the corporate governance. These recent researches highlight the extent of the interplay that exist between market liquidity and corporate governance.

In contrast with the above studies that focus on the impact of more liquid market on the strengthening of corporate governance, our study is rather concerned with the differences in liquidity due to the internal monitoring of the corporate governance mechanisms. Astonishingly enough, this relation has not been yet well studied by financial literature (Bar-Yosef \& Prencipe, 2013). Moreover, despite the existing theoretical literature analyzing the potential effect of corporate governance on liquidity, few papers have addressed this debate empirically. Chung et al. (2010), using US data, report that firms with more effective governance have more liquid equity. Prommin et al. (2014) confirm this result in Thailand. Using a sample of Chinese firms, Lei et al. (2013) show a positive relationship between governance and liquidity.

In this paper, we seek to compensate for the lack of empirical studies which mainly devoted to American and Asian markets by examining governance and liquidity using data from a European market. France possesses 
several characteristics that make it an interesting setting of studying. The governance of French firms has undergone profound transformation (Law NRE 2001, Viennot Report, 1995, 1998, Bouton Report, 2002). However, the evolution of French corporate governance system towards Anglo-Saxon one faces some resistance. The ownership structures of French corporations remain concentrated and family (Claessens et al., 2002; La Porta et al. 2000). In the vast majority of French listed firms, the deviation from the one share-one vote principle is realized through double voting rights shares (Burkart \& Lee, 2008). The takeover market remains a virtual governance mechanism (Charreaux \& Wirtz, 2007).

This paper aims to study the effect of corporate governance mechanisms while addressing the above challenges. We address the first challenge by focusing on the French firms sample. To our knowledge, the empirical relation between internal corporate governance and stock market liquidity has not yet been established in France. The examination of this relation is essential to reveal how corporate governance affects shareholder wealth. Finally, we deal with the second challenge to capture the effect of corporate governance on liquidity by adopting different measures. Initially, corporate governance is measured using a calculated governance index to capture its global effect on liquidity. Then to better explore the impact of different corporate governance determinants separately, we test a set of corporate governance sub-indexes on the different retained measures of liquidity.

Based on 1722 firm-year observations of French firms between 2007 and 2012, we show that better governance is associated with greater liquidity. The audit and the disclosure of information are the key elements that arouse the investor's interest when conducting a transaction. The type and nature of the ownership structure might be interesting for the positions on the long term, yet they do not influence the market liquidity of our sample.

The remainder of this paper is organized as follows. Section II presents the theoretical framework of the relationship between the mechanisms of governance and the stock market liquidity. Section III describes the sample and the empirical methodology. Section IV reports and discusses the results. The last section concludes the study.

\section{LITERATURE REVIEW}

In general, it is supposed by the literature that the mechanisms of governance may improve the stock market liquidity of companies. This current of research is usually based on theoretical foundations such as the agency theory (Jensen \& Meckling, 1976), the theory of entrenchment (Shleifer \& Vishny, 1989) and the stewardship theory (Davis et al. 1997).

These theories justify the relationship between the modes of governance and asymmetric information. Previous studies have established that better corporate governance is associated with more frequent and more accurate voluntary disclosure (Ajinkya et al. 2005; Donnelly \& Mulcahy, 2008). Voluntary information disclosure reduces information asymmetry (Diamond, 1985) and lowers adverse selection for investors (Coller \& Yohn, 1997). The impact of corporate governance mechanisms on market stock liquidity is thus generally explained by the risk of an adverse selection that may confront an investor in a context of asymmetric information (Glosten \& Milgrom, 1985). Indeed, a lower degree of information asymmetry and fewer agency conflicts improve stock liquidity (Brennan \& Subrahmanyam, 1995; Kyle, 1985). Large investors promote measures that improve internal corporate governance because such measures also increase stock market liquidity, which makes their exit less costly (Chung et al., 2010). In this case, it is important to recall that a system of efficient corporate governance raises the investor confidence in the markets, and furthers the establishment of more stable investment flows in the long run. This is a lever for establishing a relationship of trust between the company and investors, attracting new investors, and improving Market liquidity. According to the investors' vision, the only guarantee of the accuracy of the disclosed information is effective corporate governance (Chung et al., 2010). In fact, several researchers state that this concept makes it possible to potentially reduce the information asymmetry (Leuz \& Verrecchia, 2000). Conflicts of interests between managers and shareholders, the possibility of expropriation of minority shareholders, and embezzlement, are thus weakened. Consequently, fewer opportunities will be available to allow informed agents who take advantage of private information, at the expense of uninformed agents. Therefore, the uninformed agents will find no interest in broadening the adverse selection component of the spread and reducing share liquidity (Karmani \& Ajina, 2012). 
The theoretical work of Gillan (2006) provides a broad overview of these issues and recent work in the area. The authors review the main prior research on the impact of corporate governance on liquidity and examine how the investor protection affect stock returns and firm value. For example, several studies examine the relation between the regulatory environment and liquidity utilizing a cross country approach (Chhabra et al. 2009; La Porta et al., 2000; Shleifer \& Vishny, 1997). Using a basic definition of liquidity, the cited research considers that poor liquidity is nothing but the consequence of poor shareholder protection. Applying a comparative approach on the Hong Kong market, Brockman and Chung (2003) empirically test the relation between investor protection and firm liquidity. The authors find out that Hong Kong-based equities exhibit narrower spreads and thicker depths which was not the case of their China-based counterparts. Their results show that firm liquidity is significantly affected by investor protection.

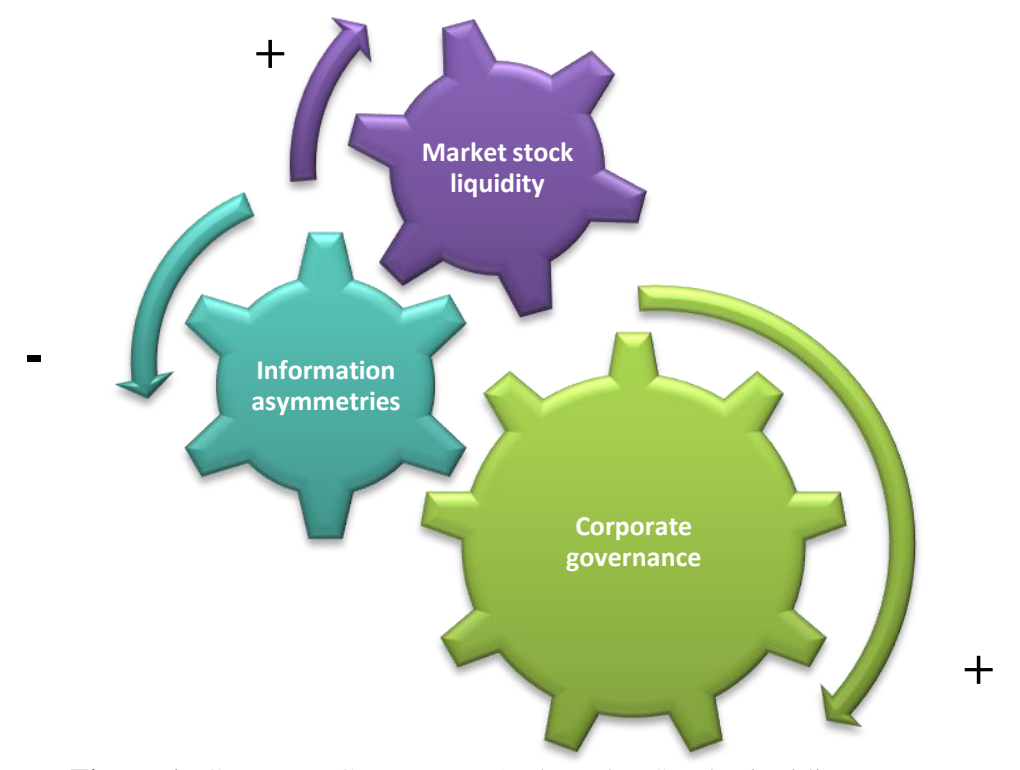

Figure 1: Corporate Governance And Market Stock Liquidity

Recently, some researchers believe that the existing relation between liquidity and corporate governance may exist in the reverse order. For example, Edmans (2009) argue that liquidity and governance may be jointly determined by firm's unobservable characteristics, or the causality may run from governance to liquidity. Bhide (1993) and Maug (2002) argue that high stock market liquidity deters internal monitoring by large shareholders. Bolton and Thadden (1998) describe that liquidity increase the incentive of large shareholders to trade on inside information rather than monitor. They show that this trade-off is related to the firm characteristics and operating environment.

According to Edmans et al. (2013) few empirical evidence treat the above relationship between corporate governance and liquidity. In general, the empirical studies suggest that the liquidity measures are correlated positively with the effectiveness of the corporate governance mechanisms. Stock market liquidity is greater for firms with a better governance structure regardless of the legal origins of the relevant country than for firms with an inferior governance structure (Chung et al. 2012). Chung et al. (2010), using US data, report that firms with more effective governance have more liquid equity.

Charoenwong et al. (2011) are also among the rare ones to have studied empirically the effect of the quality of governance on the price spread, and this, in the context of Singapore. They measure corporate governance by several criteria as discipline, transparency, independence, accountability, responsibilities, fairness, and social awareness. The authors observe that these studied mechanisms of corporate governance have an inverse relationship with the information asymmetry component (adverse selection). However, only the transparency dimension exhibits a significant inverse relationship with adverse selection. Moreover, Bar-Yosef and Prencipe (2013) study jointly the effects of corporate governance mechanisms and earnings management on market liquidity. They find that, in a 
country characterized by high ownership concentration, better corporate governance mechanisms tend to improve market liquidity in terms of both bid-ask measure and volume of trade. However, the authors notice that bid-ask measures are unaffected by earnings management, while trading volume increases when earnings management is higher, presumably due to an increase in investor disagreement. Using a sample of Chinese firms, Lei et al. (2013) show a positive relationship between governance and liquidity. Recently, Prommin et al. (2014) reveals some evidence of a relationship between corporate governance and liquidity in Thailand. In particular, they do not find a cross-sectional association between corporate governance and liquidity. However, the evidence shows that, within firms, governance quality is related to liquidity over time.

Theory consequently suggests, in most cases, that corporate governance weakness may influence stock market liquidity. According to Chung et al. (2010), liquidity is impaired since poor governance is associated with low financial and operational transparency. Therefore, we examine the effect of corporate governance on liquidity using an index of governance attributes that are likely to affect firm's liquidity. This proxy of corporate governance is more effective than to study corporate governance mechanisms independently ${ }^{1}$.

\section{DATA AND METHODOLOGY}

In this section we discuss our data sources, variable measurement and the methodology used in the study.

\subsection{Data Sources And Variables Measurement}

Our sample includes all industrial and commercial companies listed in Paris Euronext stock exchange. The initial sample is composed of 469 companies for the years 2007 to 2012. The pre-2007 period has been excluded to avoid accounting data discontinuity due to the introduction of International Financial Reporting Standards (IFRS) regulations in 2005. Financial companies were excluded. The importance of the lacking and unavailable data has left us no choice but to abandon a section of our initial sample. The final sample is composed of 287 firms. Financial data related to stock prices, trading volumes and bid and ask prices were retrieved from Thomson Reuters and Datastream. The information concerned with the governance mechanisms have been collected from Dafsaliens, Who's Who, L'état Major and the published financial reports of companies. An overview of the variables we use in our analysis and their definitions is provided in Table 1.

\subsubsection{Corporate Governance Index}

In order to test our hypothesis, we go beyond the fragmented analysis context which has so far been applied on the governance mechanisms; mechanisms that have been dealt with separately to undertake an even more systematic analysis (Charreaux, 1998). This analysis is related to the study of the whole set of the inter-connected control mechanisms (Brown \& Caylor, 2006). In fact, the corporate governance evaluation based on dimensions, undertaken separately, could not grasp the global effect of governance and its real relation to the market liquidity (Bhagat \& Bolton, 2008). Consequently, it is advisable to adopt a systematic approach which relies, at the same time, on the examination of several mechanisms as each one of them has an impact on the global efficiency of control (Agrawal \& Knoeber, 1996). In this way, the complementarity stands as a necessary condition to claim the quality of governance. Furthermore, to evaluate the quality of governance and their investment choices, the potential investors along with the market are more concerned with the efficiency of the whole set of mechanisms rather than with a single attribute (Chung et al., 2010).

Several rating agencies set the tone in terms of the evaluation of the quality of the corporate governance system. Within this analytical framework, Standard \& Poor's (2002) have launched a specific rating system in the field of corporate governance. The « Corporate Governance Score » expresses the agency opinion on the governance principles adopted by the firm; and most specifically on how they are applied. These principles are the synthesis of international policies and the actual governance procedures. For S\&P, the governance quality could be studied according to four themes; namely the ownership structure and its concentration, the nature of relationship between the different actors, the structure and functioning of the board of directors. The score is the result of the calculation

${ }^{1}$ e.g., board independence and CEO-chairman separation for the seminal work of Bar-Yosef \& Prencipe (2013). 
based on the detailed analysis of the management reports and other documents of the company. Plus, similarly to the classical rating methods, interviews with the executives of the firm are put in place. The score is based on a range of 1 to 10, from the lowest score CGS-1 to the highest one CGS-10 (Bradley, 2004).

There is another well-known metrics of corporate governance that exist. For example, the Gompers, Ishii, and Metrick (2003) index is designed with a large set of governance requirements into an index which proxies for the strength of shareholder rights, and then study the empirical relationship between this index and corporate performance. Similarly, the Institutional Shareholders Service (ISS), in 2003, developed a governance index which takes into account the 61 variables using four independent dimensions: board, compensation/remuneration, shareholder rights, and audit. Nowadays, The ISS index is composed by 181 factors analyzed under a Governance index, with the specific factors under analysis varying by region.

In our study, we use the governance index to measure the quality of governance system as a whole. The idea that underlies the creation of this index is sort of grasping the governance multiple dimensionality as well as shedding the light on the degree of the corporation compliance to the codes of best practices. The index includes internal and external corporate governance mechanisms. It was created with regard to the criterion adopted in Bouton's report which were selected by the rating agency S\&P and developed by (Brown \& Caylor, 2006) study. We selected 82 items $^{2}$, distributed around four themes namely: The board of directors ( 31 items), the audit quality (17 items), the ownership structure (16 items) and the disclosure of information (18 items). The sum of marks attributed to each item divided by the total number of items serves as an index of the quality of corporate governance.

\subsubsection{Liquidity Measure}

The theory proposes a plurality of measures for the market liquidity. These measures depend mainly on certain priorities. These latter reflect three dimensions namely the volume, the time and the price (Demsetz, 1968). Currently, the multiplicity of the evaluation methods used in the literature ${ }^{3}$ confirms the difficulty to determine the liquidity practical measure that combines these dimensions (the market efficiency coefficient, ratio illiquidity, the profundity, the trading volume and the bid ask spread). The quoted spread (bid-ask spread) measure was chosen as the major proxy of liquidity in this paper. The bid-ask spread is a measure of liquidity of firms' securities which was proposed by Demsetz (1968). A practical measure of stock market liquidity combines all of its dimensions (volume, time and price). As bid-ask spread increases the market is likely to be less liquid. The bid-ask spread addresses the adverse selection problem that arises from transacting in firm shares in the presence of asymmetrically informed investors. Less information asymmetry implies less adverse selection, which implies in turn a smaller bid-ask spread and high liquidity (Handa, Schwartz, \& Tiwari, 2003).

$$
\text { Quoted }_{-} \text {spreads }_{i, t}=\frac{A s k_{i, t}-\text { Bid }_{i, t}}{\frac{A s k_{i, t}+\text { Bid }_{i, t}}{2}}
$$

\subsubsection{Control Variables}

The theoretical and empirical literature has put into evidence the fact that the market liquidity depends on other variables than governance mechanisms namely, one of our study's concerns, the variables of interests. These variables reflect the specific characteristics of shares such as the trading volumes, price volatility, share price, the company size and the quoted market value.

Trading Volumes: The relationship between the trading volumes and liquidity is ambiguous. Hand, Holthausen, and Leftwich (1992) and Back and Pedersen (1998) assert that there is a positive correlation between those two entities. This is explained by the fact that investors tend to concentrate their trading at the same time in

\footnotetext{
${ }^{2}$ See Appendix

${ }^{3}$ Hamon, 1997 ; Kyle, 1985 ; Acharya and Pederson, 2005 ; Sadka, 2006 ; Demsetz, 1968 ; Edwards et al. 2007
} 
order to benefit from a greater liquidity. Similarly, Gregoriou et al. (2005) foresaw the same kind of relation. However, Lin et al. (1995) maintain that the trading volumes imply an adverse selection problem as the informed investors prefer to negotiate important volumes in order to take advantage from their information. So the rise of the trading volumes brings about disequilibrium in the market and leads to extra costs that have to be recouped by the enlargement of the spread. This variable is measured by the annual average of the trading volumes. We, then, expect the relationship between the spread and the trading volumes to be negative.

Price volatility: Barnea and Logue (1975) and Stoll (1978) show that volatility affects inventory holding costs and risk of stock management. It is positively associated with bid-ask spreads. Heflin et al. (2005) prove a negative relationship between liquidity and the volatility of prices. Volatility is measured by the annual average of the standard deviation of equity returns. We expect the relationship between bid-ask spreads and volatility to be positive.

Share Price: The microstructure of financial markets stipulates that the price explains a significant part of the liquidity of shares. While some authors have shown that share price is positively associated with levels of liquidity (Attig et al., 2006; Dennis \& Weston, 2001), others advocate a negative relationship between the price of shares and their liquidity (Heflin et al., 2005).This variable is measured by the average of the daily closing prices of each year. We expect a negative relationship between share price and bid-ask spreads.

Firm size : It is considered as a proxy of information asymmetry and agency costs. Demsetz (1968) suggests that small companies incur high level of information asymmetry. Moreover, equities firms with weak market capitalization are less liquid (Chiang \& Venkatesh, 1988; Laux, 1993). Smaller firms' stocks may exhibit greater spreads due to their low liquidity (Khan et al., 2005). Consequently, we anticipate a positive association between firm size and bid-ask spreads. It is measured by the natural logarithm of year-end market capitalization.

Listing in the U.S Market : The listing on overseas investments, and more particularly in U.S. markets, is considered as one of the essential characteristics that may influence the decision of publication. Indeed, when a company is publicly listed on U.S. markets, it must comply with the requirements of these markets and publish its accounts under U.S.GAAP. El-Gazzar et al., (1999), Lins et al., (2005) and Botosan (2006) argue that trading on more than one market is among the reasons that may motivate leaders to become more inclined to inform the market. The application of these standards and subsequently the higher level of published information is perceived as a positive signal by the market, thereby increasing confidence among investors. This is likely to attract investors to invest in these companies, thus increasing the volume of transactions. We expect a positive association between listing on the U.S. market and liquidity.

Table 1: Summary Of Variables

\begin{tabular}{|c|c|c|c|}
\hline & Variable Name & Description & Measure \\
\hline \multirow{5}{*}{ 苞 } & Ind_Gov & Corporate governance index & 82 items \\
\hline & Ind_conse & Bord of directors index & 31 items \\
\hline & Ind_aud & Audit index & 17 items \\
\hline & Ind_actio & Ownership structure index & 16 items \\
\hline & Ind_divul & Disclosure index & 18 items \\
\hline \multirow{5}{*}{ 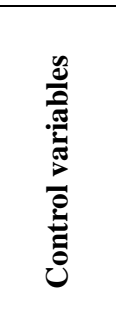 } & LnVOLM & Trading Volumes & $\begin{array}{c}\text { Annual average } \\
\text { of the trading volumes }\end{array}$ \\
\hline & LnVOLAT & Price volatility & $\begin{array}{c}\text { Annual average of the standard } \\
\text { deviation of equity returns }\end{array}$ \\
\hline & LnPRICE & Share Price & $\begin{array}{c}\text { Average of the daily } \\
\text { closing prices of each year }\end{array}$ \\
\hline & $\operatorname{LnCB}$ & Firm size & $\begin{array}{c}\text { Natural logarithm of year-end } \\
\text { market capitalization }\end{array}$ \\
\hline & USCOT & Listed in the U.S Market & Dummy variable \\
\hline
\end{tabular}




\subsection{Methodology}

The multiple regression methodology with panel data is used. Panel data analyses include two special dimensions: an individual dimension, as indicated by the $i$ index, standing for the company, and a $t$ index standing for the period dimension (Gujarati, 2004). The Hausman test is used to choose between fixed effect and random effect models. The results of the Hausman test, not reported here, show that the fixed effect model is preferable to the random effect. This method permit to focus on changes in the variables over time to estimate the effects of the independent variables on dependent variable. In our study, we have considered the effects of the global corporate governance index on liquidity (Model 1). Then, the separate effect of the different determinants of corporate governance (the retained sub-indexes) on market stock liquidity (Model 2, Model 3, Model 4 and Model 5) was examined. An overview of the models used in our analysis is provided in Table 2.

Table 2: Models

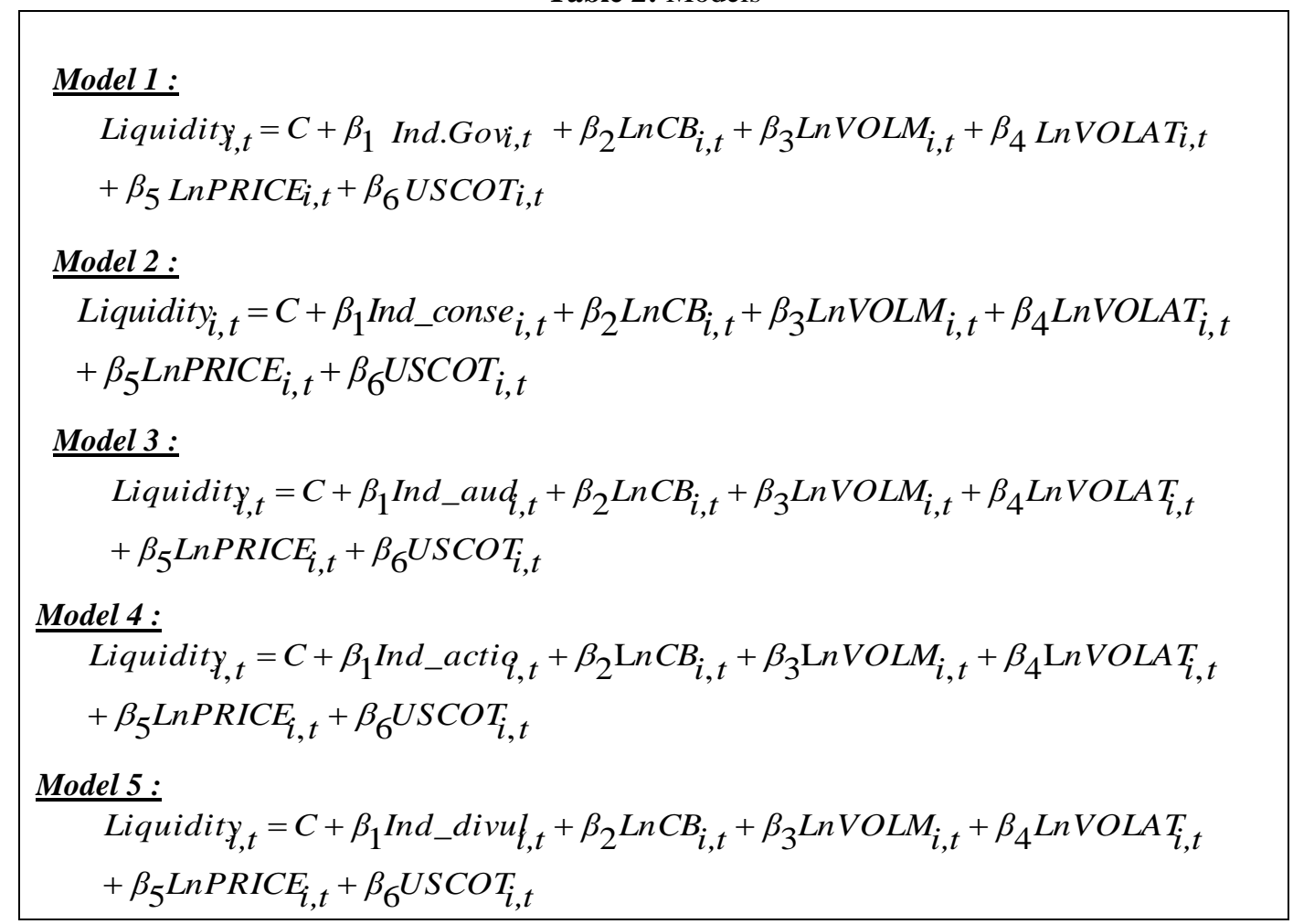

\section{ANALYSIS AND DISCUSSION}

In this section, we examine how our corporate governance indexes are related to our liquidity measures.

\subsection{Descriptive Statistics}

Table 3 illustrates the descriptive statistics of the global index as well as the sub-indexes. We notice that the governance index is on average in the order of $51.01 \%$. This leaves us to note that the French companies of our sample in terms of quality are above average. However, it is necessary to bring improvements in order to have a better governance quality. We also observe that the higher index is that of the disclosure of information. The transparency seems to be one of the major priorities of the French regulation that would aim to the safeguard of the investors' security. In other words, all these scores display relatively low standard deviation. This implies that the French companies are aware of the importance of these mechanisms impact on the quality governance system. It seems also that the criterion of the governance efficiency of our sample do not have the same importance and effect differently the governance quality. We also note that the displayed price spread is on average equal to $0.51 \%$ while 
we observe a lower one in the Anglo-Saxon markets. In fact, Heflin et al. (2005) found out that the price spread in North-America is in the order of $0.162 \%$. Sarin, Shastri, and Shastri (2000) set the level of the spread to an average of 0.012 in the United States. Consequently, we consider that the French financial market is less liquid than the Anglo-Saxon markets.

Table 3: Descriptive Statistics

This table illustrates the descriptive statistics of different indexes. Ind_glob: Global index of the corporate governance quality, Ind_conse: board of directors index, Ind_aud: Index of the audit committee, Ind_actio:index of the ownership structure, Ind_divul: index of the transparency and the disclosure of information. BASP : bid-ask spread, ESP: effective spread.

\begin{tabular}{l|ccccccc}
\hline & Ind_GOV & Ind_conse & Ind_aud & Ind_actio & Ind_divul & BASP & ESP \\
\hline Mean & 0,6324 & 0,3864 & 0,5832 & 0,4298 & 0,8122 & 0,0051 & 0,031 \\
Median & 0,6528 & 0,3899 & 0,6152 & 0,4836 & 0,8273 & 0,008 & 0,029 \\
Max & 0,7421 & 0,7825 & 0,8899 & 0,8395 & 1 & 0,091 & 0,157 \\
Min & 0,2461 & 0,0296 & 0,1781 & 0,1902 & 0,3988 & 0,0007 & 0 \\
Std. Dev. & 0,1452 & 0,1888 & 0,1912 & 0,1395 & 0,1458 & 3,711 & 2,832 \\
\hline
\end{tabular}

\subsection{Results And Discussion}

Table 4 shows that the selected governance index affects, in a negative way, the displayed spread. Consequently, it may be deduced that the corporations adopting a big number of recommendations implemented in the items selected for the measurement of governance quality proved to have a better market liquidity. The higher is the index, the more liquid are the stock liquidity. Generally speaking, this confirms that good governance allows lowering the degree of uncertainty concerning the corporate stocks of our sample. When evaluating the governance quality and the choice of investment, the potential investors and the market take into consideration the efficiency of all mechanisms and not only a single attribute. This result is coherent with the former modelings as well as confirms the one found out by Chung et al. (2010) and Charoenwong et al. (2011). These latter have shown that a governance index increase of $1 \%$, is, on average, associated to $1.2 \%$ increase in the transactions volume. Moreover, we have also ran regressions using the sub-indexes with regard to the four governance axes; namely the board of directors' characteristics, the audit, the ownership structure, and the disclosure of information. The examination of the effect of the governance sub-indexes on the liquidity corroborates the result of the global governance index. However, this is not the case for the ownership structure index which reveals a non-significant coefficient. This might indicate that the board of directors' sub-indexes, the audit and the disclosure of information are the key elements that arouse the investor's interest when conducting a transaction. The type and nature of the ownership structure might be interesting for the positions on the long term, yet they do not influence the market liquidity of our sample.

The link between the transactions volume and the price spread is negative and statistically significant to a level of $1 \%$. This means that higher transactions volume would entail both weaker shares detention and information research costs and more liquid the market will be. The intensity of the activity that the transactions volume measures is usually displayed in the bid/ask spread as this activity determines the risk level covered by the investors in terms of inventory of trading stock. In fact, the transactions volume is often associated with the operators increased ability to execute transaction with little impact on the price. These transactions, in their turn, alleviate the risk linked to the conservation of stocks and so to narrow the interbank bid-ask spread. This result is in compliance with predictions of Chae (2005) and Heflin et al. (2005).

The volatility of prices influences positively and in a significant way the stock spread. The rise of the volatility and of the profitability of an asset increases the probability to negotiate with an informed investor. The investors will tend to increase the bid price and decrease the ask one. This would entail both the widening of the price spread and the reduction of liquidity. And here, the result is in compliance with the observations of Espinosa et al. (2008).

The variable coefficient «price of the security » is negative and significant. This result indicates that stocks with low trading have larger price spreads. This relation depends, to a large extent, on the cost of the processing of payment orders. These costs are regressive to the price as they are allocated on a bigger amount of currency units for the high price shares (Stoll, 1978). 
Table 4: Regressions Results

LnBASP : is the neperian logarithm of the displayed price spread ; Ind_glob, Ind_conse, Ind_aud, Ind_actio, Ind_divul are respectively: global index, board of directors index, audit index, ownership structure index and quality of information disclosure index ; LNVOLM: is the neperian logarithm of the transactions volume annual average ; LnCB: is the firm size measured by neperian logarithm of the market capitalization annually at the end of December ; VOLT : is the annual average of the standard deviation of the daily returns ; LnPRICE: is the average stock price for each year daily closing USCOT : equal to 1 if the firm is listed in the American markets ; if not 0.

\begin{tabular}{|c|c|c|c|c|c|c|c|c|c|c|}
\hline & $\begin{array}{l}\text { LnB } \\
\text { (Mod }\end{array}$ & & $\begin{array}{l}\text { LnB } \\
(\mathrm{Moc}\end{array}$ & & $\begin{array}{l}\mathrm{LnB} \\
(\mathrm{Moc}\end{array}$ & & $\begin{array}{l}\mathrm{LnB} \\
(\mathrm{Moc}\end{array}$ & & $\begin{array}{l}\text { LnB } \\
(\mathrm{Moc}\end{array}$ & \\
\hline Constante & $-4,158 * * *$ & $-6,31$ & $-4,323 * * *$ & $-6,1$ & $-4,21 * * *$ & $-5,85$ & $-3,92 * * *$ & $-5,54$ & $-4,23 * * *$ & $-5,62$ \\
\hline Ind Gov & $-0,152 * *$ & $-2,75$ & & & & & & & & \\
\hline Ind_conse & & & $-0,141 * *$ & $-2,01$ & & & & & & \\
\hline Ind_aud & & & & & $-0,423 * *$ & $-1,99$ & & & & \\
\hline Ind_actio & & & & & & & $-0,081$ & $-1,25$ & & \\
\hline Ind_divul & & & & & & & & & $-0,569 * *$ & $-2,72$ \\
\hline LnCB & $-0,191 * * *$ & $-6,25$ & $-0,164 * * *$ & $-5,3$ & $-0,162 * * *$ & $-5,29$ & $-0,163 * * *$ & $-6,08$ & $-0,159 * * *$ & $-6,51$ \\
\hline LnVOLM & $-0,132 * * *$ & $-4,42$ & $-0,152 * * *$ & $-4,5$ & $-0,151 * * *$ & $-6,52$ & $-1,795 * *$ & $-5,99$ & $-0,15 * * *$ & $-5,69$ \\
\hline LnVOLA & $0,211 * *$ & 1,98 & $0,261 * *$ & 1,99 & $0,212^{*}$ & 1,94 & $0,251 * *$ & 2,13 & $0,401 * *$ & 1,98 \\
\hline LnPRICE & $-0,052$ & $-0,91$ & $-0,09$ & $-0,8$ & $-0,111$ & $-0,89$ & $-0,151$ & $-0,92$ & $-0,16$ & $-0,85$ \\
\hline USCOT & $-0,281 * *$ & $-1,99$ & $-0,311 * *$ & $-2,14$ & $-0,263 * *$ & $-1,99$ & $-0,393 * *$ & $-1,98$ & $-0,48 * * *$ & $-2,85$ \\
\hline $\mathbf{R}^{2}$ & 0,32 & & 0,33 & & 0,34 & & 0,36 & & 0,38 & \\
\hline F-statistic & $19,58(0,0)$ & & $20,12(0,0$ & & $20,46(0,0$ & & $22,38(0,0$ & & $25,06(0,0$ & \\
\hline
\end{tabular}

***, **, and * indicate significance at the $1 \%, 5 \%$, and $10 \%$ levels, respectively.

Table 4 also shows that the price spread declines according to the rise of the company size. This result converges towards the idea claiming that smaller capitalization firms are less liquid than highly capitalized one. This observation coincides with LaFond et al. (2007) earlier findings. Concerning the American market, the pricing variable is negatively associated with the price spread. This result confirms the listed companies in the American market publish more informative annual reports. These companies adopt the US GAAP. These latter are more demanding in terms of information; which explains the positive effect on the liquidity of stocks. The distinction between the IFRS and the US GAAP is meaningful due to the literature awareness of their different influence on investors in terms of informational value (Bischof \& Daske, 2013).

\section{ROBUSTNESS CHECKS}

In this section, we check the robustness of our results obtained using other measure of liquidity. In particular, we follow Amihud (2002) by using effective spread and Illiquidity ratio as proxies of liquidity.

Effective spread: is the difference between the price of a newly issued stock and its actual price with an adjustment for the effect of the offering's announcement. The quoted spreads are the posted costs of the market, while the effective spread is used to capture the transaction costs (Callahan et al. 1997). Locke and Venkatesh (1997) and Ferguson and Mann (2001) show that quoted spread estimators are unrelated to the aggregate customer execution costs in futures markets. The effective spread better captures the cost of a round-trip order by including price movement. This second measure indicates the narrowness of the market and the immediacy of the market by indicating the volume on the purchase or sale that can be instantly absorbed by the supply or demand. Heflin et al. (2005) suggest that effective spreads are likely to be a better spread-based measure for the liquidity of stocks than either raw or relative spreads. In an order-driven market, ask is the best price associated with a selling limit order, whereas, bid is the price associated with a buying limit order.

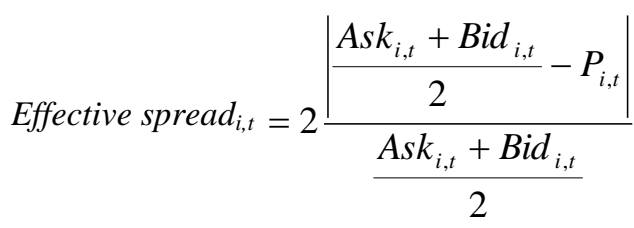

Asset non-liquidity: is based on the relationship between the performance and the volume as defined by Amihud (2002). It takes into account two dimensions of the market liquidity: depth, i.e. the volume of units that can 
be traded without significantly impacting prices, and resilience, i.e. the speed with which fluctuations due to transactions disappear. For one asset class, the mean illiquidity ratio is defined by (multiplied by $10^{6}$ ):

Illiquidity ratio $_{i, t}=\frac{1}{D_{j}} \sum \frac{\left|R_{j}\right|}{\left(\operatorname{Vol}_{j} * P_{j}\right)}$

With $\mathrm{D}_{\mathrm{j}}$ to represent the number of days an asset has been quoted, $\left|R_{j}\right|$ the absolute vale of daily return, $\mathrm{Vol}_{\mathrm{j}}$ the volume of daily transactions, and $\mathrm{Pj}$ the asset quotation on d day. Hasbrouck (2002) assumes that this measure is the best one to capture Kyle's lamba. This measurement is based on the days without price changes, which is an advantage. This ratio is positively associated with the bid-ask spread; a small bid-ask spread is linked with a limited impact on prices (Lesmond, 2005).

Table 5: Regressions Results

ESP: is the logarithm of the averaged effective spread. LnVOLM: is the logarithm of the averaged volume exchanged. ILLIQ: is illiquidity ratio. Ind_glob: global index, LNVOLM: is the neperian logarithm of the transactions volume annual average; LnCB: is the firm size measured by neperian logarithm of the market capitalization annually at the end of December; VOLT : is the annual average of the standard deviation of the daily returns ; LnPRICE: is the average stock price for each year daily closing USCOT : equal to 1 if the firm is listed in the American markets ; if not 0 .

\begin{tabular}{lcc|rc}
\hline & & & ILLIQ \\
\hline Constante & $-3,201 * * *$ & & $-5,69$ \\
Ind_Gov & $-0,328 * *$ & $-5,42$ & $-4,283 * * *$ & $-3,82$ \\
LnCB & $-0,210^{* * *}$ & $-2,91$ & $-0,435 * * *$ & $-5,68$ \\
LnVOLM & $-0,141^{* * *}$ & $-5,61$ & $-0,263 * * *$ & $-7,16$ \\
LnVOLA & $0,211^{* *}$ & $-5,03$ & $-0,235 * * *$ & 3,85 \\
LnPRICE & $-0,162$ & 2,02 & $0,308 * * *$ & $-0,83$ \\
USCOT & $-0,347 * *$ & $-0,103$ & $-3,28$ \\
\hline $\mathbf{R}^{2}$ & $-1,20$ & $-0,409 * * *$ & \\
\hline F-statistic & $-2,25$ & $32,91(0,000)$ & \\
$* * *, * *$, and $*$ indicate significance at the $1 \%, 5 \%$, and $10 \%$ levels, respectively.
\end{tabular}

We report the results of effective spread and illiquidity ratio regressions in table 5. The results remain unchanged for all of our variables. We find that spreads are negatively and significantly related to governance index. These results provide further evidence that better corporate governance improves stock market liquidity.

\section{CONCLUSION}

The purpose of this paper is to test empirically the effect of corporate governance on stock market liquidity. While prior literature generally suggests that the level of liquidity has an impact on corporate governance mechanisms, the empirical evidence regarding the impact of corporate governance characteristics on firm's market liquidity is quite limited (Edmans, 2009). Prior research suggests that companies with poor governance structure have lower market values (Chung et al. 2010). Therefore, firms with better corporate governance are likely to have more liquid markets for their shares because of the financial transparency, which eventually decreases information asymmetries and impose more monitoring on managers.

In this study, a set of variables of corporate governance and market liquidity was measured for 287 French companies. The data was collected between 2007 and 2012. Our results show that, in a setting characterized by high ownership concentration and after controlling for its level, better corporate governance practices tend to improve market liquidity in terms of quoted spread. This is confirming that the market consider that such indicators aid in evaluating the risk of information asymmetry. This proves that good governance tends to reduce uncertainty in the securities of companies in our sample. Firms with higher liquidity have lower costs of capital, and as a consequence, higher firm value, lower required returns from investors.

Theoretically, this study contributes to the growing literature on determinants that drive liquidity in stock markets. First of all, we supplement the existing literature (Chung et al. (2010), etc) by examining the relation 
between the corporate governance effectiveness and the stock market liquidity from a sample of panel data and on the basis of French listed companies, which are different in terms of financial characteristics and corporate governance. We show that the influence of corporate governance on stock liquidity depends on overall indexes and sub-indexes of corporate governance and not only on an isolated specific mechanisms. We found that more effective corporate governance, reflected by a superior board, audit and disclosure indexes, is a key elements of wellfunctioning financial markets. Indeed, our corporate governance proxies provide more accurate results of our examination compared to prior research.

In term of managerial implications, investors react positively to the quality of the disclosed information. It may be an interesting lever which companies may integrate in their financing strategy. As a result, firm can enhance its liquidity by increasing the insurance of investors. Then the disclosed information may be enhanced by the presence of an effective board of directors and financial expertise. Consequently, in countries with poor protection shareholders, better disclosure leads to higher market liquidity by the presence of other effective corporate governance mechanisms.

This conclusions may have important implications in terms of the academic and managerial understanding toward the advantages and the cost of the corporate governance. While the results in this paper provide some evidence on liquidity determinants, there are still ample areas for future research. The results of our study are specific to the French context. Therefore, subsequent studies should analyze other financial markets to confirm our findings.

\section{AUTHOR INFORMATION}

Majdi Karmani, Ph.D, Department of Finance, IRGO Lab, La Rochelle Business School, 102, rue de Coureilles Les Minimes - 17024 La Rochelle Cedex 1, France. E-mail: karmanim@esc-larochelle.fr. (Corresponding author)

Aymen Ajina, Ph.D, Department of Finance, HEC-Business School - University of Liege Faculty of Economic Sciences and Management of Sousse Member of the LAMIDED. E-mail: ayman.ajina@gmail.com

Rym Boussaada, Ph.D, in finance. She was a research assistant at Kedge Business School Bordeaux. She is an affiliate researcher with GEF2A ( Laboratoire Gouvernance d'Entreprise, Finance Appliquée et Audit-University of Tunis, High Institure of Management). Her current research interests include bank governance, corporate governance and CEO remuneration. E-mail: boussaada.r@gmail.com

\section{REFERENCES}

Agrawal, A., \& Knoeber, C. R. (1996). Firm performance and mechanisms to control agency problems between managers and shareholders. Journal of financial and quantitative analysis, 31(03), 377-397.

Ajinkya, B., Bhojraj, S., \& Sengupta, P. (2005). The association between outside directors, institutional investors and the properties of management earnings forecasts. Journal of accounting research, 43(3), 343-376.

Amihud, Y. (2002). Illiquidity and stock returns: cross-section and time-series effects. Journal of financial markets, $5(1), 31-56$.

Attig, N., Fong, W.-M., Gadhoum, Y., \& Lang, L. H. (2006). Effects of large shareholding on information asymmetry and stock liquidity. Journal of Banking \& Finance, 30(10), 2875-2892.

Back, K., \& Pedersen, H. (1998). Long-lived information and intraday patterns. Journal of financial markets, 1(3), 385-402.

Bar-Yosef, S., \& Prencipe, A. (2013). The Impact of Corporate Governance and Earnings Management on Stock Market Liquidity in a Highly Concentrated Ownership Capital Market. Journal of Accounting, Auditing \& Finance, 28(3), 292-316.

Barnea, A., \& Logue, D. E. (1975). The effect of risk on the market maker's spread. Financial Analysts Journal, 4549.

Bhagat, S., \& Bolton, B. (2008). Corporate governance and firm performance. Journal of Corporate Finance, 14(3), 257-273.

Bhide, A. (1993). The hidden costs of stock market liquidity. Journal of financial economics, 34(1), 31-51. 
Bischof, J., \& Daske, H. (2013). Mandatory Disclosure, Voluntary Disclosure, and Stock Market Liquidity: Evidence from the EU Bank Stress Tests. Journal of accounting research, 51(5), 997-1029.

Bolton, P., \& Thadden, V. (1998). Blocks, liquidity, and corporate control. The journal of finance, 53(1), 1-25.

Botosan, C. A. (2006). Disclosure and the cost of capital: what do we know? Accounting and business research, $36(\sup 1), 31-40$.

Bradley, N. (2004). Corporate governance scoring and the link between corporate governance and performance indicators: in search of the Holy Grail. Corporate Governance: An International Review, 12(1), 8-10.

Brennan, M. J., \& Subrahmanyam, A. (1995). Investment analysis and price formation in securities markets. Journal of financial economics, 38(3), 361-381.

Brockman, P., \& Chung, D. Y. (2003). Investor protection and firm liquidity. The journal of finance, 58(2), 921938.

Brown, L. D., \& Caylor, M. L. (2006). Corporate governance and firm valuation. Journal of Accounting and Public Policy, 25(4), 409-434.

Burkart, M., \& Lee, S. (2008). One share-one vote: the theory. Review of Finance, 12(1), 1-49.

Callahan, C. M., Lee, M., \& Yohn, T. L. (1997). Accounting information and bid-ask spreads. Accounting horizons, $11(4), 50-60$.

Chae, J. (2005). Trading volume, information asymmetry, and timing information. The journal of finance, 60(1), 413-442.

Charoenwong, C., Ding, D. K., \& Siraprapasiri, V. (2011). Adverse selection and corporate governance. International Review of Economics \& Finance, 20(3), 406-420. doi: 10.1016/j.iref.2010.11.011

Charreaux, G. (1998). Le point sur la mesure de performance des entreprises. Banque et Marchés, 34, 46-51.

Charreaux, G., \& Wirtz, P. (2007). Corporate governance in France. . Working paper FARGO N 1070201.

Chhabra, M., Ferris, S. P., \& Sen, N. (2009). Investor protection effects on corporate liquidity and the cost of capital. Applied Economics Letters, 16(8), 819-826. doi: 10.1080/13504850701221915

Chiang, R., \& Venkatesh, P. (1988). Insider holdings and perceptions of information asymmetry: A note. The journal of finance, 43(4), 1041-1048.

Chung, K. H., Elder, J., \& Kim, J.-C. (2010). Corporate Governance and Liquidity. Journal of Financial \& Quantitative Analysis, 45(2), 265-291.

Chung, K. H., Kim, J. S., Park, K., \& Sung, T. (2012). Corporate governance, legal system, and stock market liquidity: evidence around the world. Asia-Pacific Journal of Financial Studies, 41(6), 686-703.

Claessens, S., Djankov, S., Fan, J. P., \& Lang, L. H. (2002). Disentangling the incentive and entrenchment effects of large shareholdings. The journal of finance, 57(6), 2741-2771.

Coller, M., \& Yohn, T. L. (1997). Management forecasts and information asymmetry: An examination of bid-ask spreads. Journal of accounting research, 181-191.

Davis, J. H., Schoorman, F. D., \& Donaldson, L. (1997). Toward a stewardship theory of management. Academy of Management review, 22(1), 20-47.

Demsetz, H. (1968). The cost of transacting. The Quarterly Journal of Economics, 82(1), 33-53.

Dennis, P. J., \& Weston, J. P. (2001). Who's informed? An analysis of stock ownership and informed trading. McIntire School (Virginia) working paper.

Diamond, D. W. (1985). Optimal release of information by firms. The journal of finance, 40(4), 1071-1094.

Donnelly, R., \& Mulcahy, M. (2008). Board structure, ownership, and voluntary disclosure in Ireland. Corporate Governance: An International Review, 16(5), 416-429.

Edmans, A. (2009). Blockholder Trading, Market Efficiency, and Managerial Myopia. Journal of Finance, 64(6), 2481-2513. doi: 10.1111/j.1540-6261.2009.01508.x

Edmans, A., Fang, V. W., \& Zur, E. (2013). The Effect of Liquidity on Governance. Review of Financial Studies, 26(6), 1443-1482.

El-Gazzar, S. M., Finn, P. M., \& Jacob, R. (1999). An empirical investigation of multinational firms' compliance with international accounting standards. The International Journal of Accounting, 34(2), 239-248.

Espinosa M., Tapia M. \& Trombetta M. (2008). Disclosure and liquidity in a driven by orders market: Empirical evidence from panel data. Investigaciones Economicas, 32 (3),339-369.

Gillan, S. L. (2006). Recent developments in corporate governance: an overview. Journal of Corporate Finance, 12(3), 381-402.

Glosten, L. R., \& Milgrom, P. R. (1985). Bid, ask and transaction prices in a specialist market with heterogeneously informed traders. Journal of financial economics, 14(1), 71-100. 
Gompers, P., Ishii, J., \& Metrick, A. (2003). Corporate governance and equity prices. The Quarterly Journal of Economics, 118(1), 107-156.

Gregoriou, A., Ioannidis, C., \& Skerratt, L. (2005). Information Asymmetry and the Bid- Ask Spread: Evidence From the UK. Journal of Business Finance \& Accounting, 32(9-10), 1801-1826.

Gujarati, D. (2004). Basic Econometrics. United States Military Academy, West Point: Tata McGraw-Hill.

Hand, J. R., Holthausen, R. W., \& Leftwich, R. W. (1992). The effect of bond rating agency announcements on bond and stock prices. The journal of finance, 47(2), 733-752.

Handa, P., Schwartz, R., \& Tiwari, A. (2003). Quote setting and price formation in an order driven market. Journal of financial markets, 6(4), 461-489.

Heflin, F. L., Shaw, K. W., \& Wild, J. J. (2005). Disclosure Policy and Market Liquidity: Impact of Depth Quotes and Order Sizes. Contemporary Accounting Research, 22(4), 829-865.

Jensen, M. C., \& Meckling, W. H. (1976). Theory of the firm: Managerial behavior, agency costs and ownership structure. Journal of financial economics, 3(4), 305-360.

Karmani, M., \& Ajina, A. (2012). Market Stock Liquidity and Corporate Governance. Paper presented at the 29th International Conference of the French Finance Association (AFFI), Strasbourg

Khan, W. A., Kent Baker, H., Chaudlhy, M. \& Maheshwari, S. K. (2005). The impact of insider trading on market liquidity in the NASDAQ market. Journal of Applied Business Research, 21(4), 11-22.

Kyle, A. S. (1985). Continuous auctions and insider trading. Econometrica: Journal of the Econometric Society, 1315-1335.

La Porta, R., Lopez-de-Silanes, F., Shleifer, A., \& Vishny, R. (2000). Investor protection and corporate governance. Journal of financial economics, 58(1), 3-27.

LaFond, R., Lang, M., \& Skaife, H. (2007). Earnings smoothing, governance and liquidity: international evidence. Working Paper SSRN.

Laux, P. A. (1993). Trade sizes and theories of the bid-ask spread. Journal of Financial Research, 16(3), 237-249.

Lei, Q., Lin, B., \& Wei, M. (2013). Types of agency cost, corporate governance and liquidity. Journal of Accounting and Public Policy, 32(3), 147-172.

Leuz, C., \& Verrecchia, R. E. (2000). The economic consequences of increased disclosure. Journal of accounting research, 91-124.

Lin, J.-C., Sanger, G. C., \& Booth, G. G. (1995). Trade size and components of the bid-ask spread. Review of Financial Studies, 8(4), 1153-1183.

Lins, K. V., Strickland, D., \& Zenner, M. (2005). Do non-US firms issue equity on US stock exchanges to relax capital constraints? Journal of financial and quantitative analysis, 40(01), 109-133.

Maug, E. (2002). Insider trading legislation and corporate governance. European Economic Review, 46(9), 15691597.

Prommin, P., Jumreornvong, S., \& Jiraporn, P. (2014). The effect of corporate governance on stock liquidity: The case of Thailand. International Review of Economics \& Finance, 32, 132-142.

Sarin, A., Shastri, K. A., \& Shastri, K. (2000). Ownership structure and stock market liquidity. Intl. J. Accoun, 38, 465-491.

Shleifer, A., \& Vishny, R. W. (1989). Management entrenchment: The case of manager-specific investments. Journal of financial economics, 25(1), 123-139.

Shleifer, A., \& Vishny, R. W. (1997). A survey of corporate governance. The journal of finance, 52(2), 737-783.

Stoll, H. R. (1978). The pricing of security dealer services: An empirical study of NASDAQ stocks. The journal of finance, 33(4), 1153-1172. 
APPENDIX: Composition of the retained corporate governance indexes

\section{Composition of the board of directors' index}

\begin{tabular}{|c|c|}
\hline 1 & The number of directors in the board of directors is between 5 and 12 \\
\hline 2 & The board of directors is composed by at least $50 \%$ of independent administrators \\
\hline 3 & The separation between the functions of the chairman of the board of directors and the company director general \\
\hline 4 & The meetings of the board of directors are held at least once per trimester ( 4 times a year) \\
\hline 5 & At least $80 \%$ of the directors attend the meetings \\
\hline 6 & The average duration of the meeting lasts for more than 2 hours \\
\hline 7 & The term of office of a director does not exceed 4 years \\
\hline 8 & The presence of a paid official in the board of directors \\
\hline 9 & The presence of institutional directors in the board of directors \\
\hline 10 & The re-election of the board chairman \\
\hline 11 & The re-election of the executive directors \\
\hline 12 & The renewal of mandate of the chairman of the board \\
\hline 13 & The renewal of the mandate of the executive directors \\
\hline 14 & The existence of a nomination committee \\
\hline 15 & The nomination committee is composed by $2 / 3$ directors \\
\hline 16 & The nomination committee meets at least 2 times a year \\
\hline 17 & The nomination committee provides an overview of the activities \\
\hline 18 & At least $80 \%$ of the nomination committee members are present in the meetings \\
\hline 19 & The existence of a remuneration committee \\
\hline 20 & The remuneration committee is composed by $2 / 3$ independent directors \\
\hline 21 & The remuneration committee meets at least 2 times a year \\
\hline 22 & At least $80 \%$ of the committee members are present in the meetings \\
\hline 23 & The remuneration committee provides recommendations on the remuneration of the executive directors \\
\hline 24 & The existence of a governance committee \\
\hline 25 & The governance committee meets at least 2 times a year \\
\hline 26 & The existence of a strategic committee \\
\hline 27 & The strategic committee meets at least 2 times a year \\
\hline 28 & The existence of an investment committee \\
\hline 29 & The investment committee meets at least 2 times a year \\
\hline 30 & The existence of a finance committee \\
\hline 31 & The finance committee meets at least 2 times a year \\
\hline
\end{tabular}

\section{Composition of the audit index}

\begin{tabular}{cl}
\hline 1 & The external auditor belongs to the Big 4. \\
\hline 2 & The mandate with the company is limited to 6 years. \\
\hline 3 & The existence of a double auditorship. \\
\hline 5 & The existence of a statutory auditors' report on consolidated accounts. \\
\hline 6 & The existence of a statutory auditors' report on the internal control. \\
\hline 7 & The existence of an audit committee. \\
\hline 8 & The audit committee meets at least 4 times a year. \\
\hline 10 & The attendance rate to the committee meetings is superior to $2 / 3$. \\
\hline 11 & The existence of an accounting expert in the audit committee. \\
\hline 12 & The audit committee submits a report on its activities and its operating procedures to the board of administrators. \\
\hline 13 & The audit committee has the internal audits reports. \\
\hline 14 & The audit committee checks the external audit report. \\
\hline 15 & The audit committee meets with the auditor in the absence of the director. \\
\hline 16 & The renewal Statutory auditors mandate. \\
\hline 17 & The re-election of the Statutory auditors. \\
\hline
\end{tabular}




\section{Composition of the ownership structure index}

\begin{tabular}{cl}
\hline 1 & The first shareholder holds more than $10 \%$ in the company \\
\hline 2 & The second shareholder holds no more than $10 \%$ \\
\hline 3 & The two first shareholders hold no more than $50 \%$ in the company \\
\hline 5 & The existence of information about the capital key of the company \\
\hline 6 & The majority shareholder is not family \\
\hline 7 & There is no shareholders' agreements \\
\hline 8 & The public holds no more than 50\% \\
\hline 9 & The currency property vote exceeds $10 \%$ \\
\hline 10 & The existence of institutional investors \\
\hline 11 & The institutional investor holds no more than $10 \%$ in the company \\
\hline 13 & The existence of foreign institutional investors \\
\hline 14 & The existence of an employee shareholder \\
\hline 15 & The managerial ownership is between $5 \%$ and $25 \%$ \\
\hline 16 & The state shareholder in the company
\end{tabular}

\section{Composition of the quality of information disclosure index}

\begin{tabular}{ll}
\hline 1 & The company provides the investors with trimestrial reports \\
\hline 2 & The company provides the investors with semestrial reports \\
\hline 3 & The financial statements are also presented in accounting standards (IAS/IFRS) \\
\hline 4 & The remuneration disclosure of the corporate officers \\
\hline 6 & The detailed remuneration disclosure of the officers \\
\hline 7 & The publication of the fees amount paid by the company to the external auditors \\
\hline 8 & The disclosure of the arrangement for paying the attendance fees \\
\hline 9 & $\begin{array}{l}\text { The annual reports include a specific section that describes the corporate governance model / the governance } \\
\text { current practice }\end{array}$ \\
\hline 10 & The disclosure of the administrators level of education /profiles \\
\hline 11 & The acquisition/sale disclosure \\
\hline 13 & The annual report provides the company policy in R\&D \\
\hline 14 & The disclosure of the right to vote \\
\hline 15 & The disclosure of the risk factors \\
\hline 16 & The declaration of both the company current and future strategy and its financial and marketing general goals \\
\hline 18 & Dhe annual report includes the profits estimation or the prediction of financial returns \\
\hline
\end{tabular}




\section{NOTES}

